\title{
Investigation of Water Losses in Water Supply System: Muscat as a Case Study
}

\author{
Manal M. Al-Bulushi ${ }^{1}$, Maha M. Al Sulti ${ }^{1}$, and Mohammed F.M. Abushammala ${ }^{1,{ }^{*}}$ \\ ${ }^{1}$ Department of Civil Engineering, Middle East College, Knowledge Oasis Muscat, P.B. No 79, Al \\ Rusayl 124, Sultanate of Oman
}

\begin{abstract}
One of the problems affecting water supply systems in Oman is the problem of water loss and Non-Revenue Water (NRW). The aim of this research is to carry out water auditing for Al Seeb water distribution network as a case study to estimate the water losses, NRW, water balance, and the resulting financial and operational impacts. Annual data on water supplies, water consumption, system data, and cost data for the years from 2010 to 2014 was collected from the Public Authority for Electricity and Water (PAEW) and the analysis was done using the American Water Works Association (AWWA) audit software to determine water losses including real and apparent losses, NRW, water balance, and the cost. The results indicated that the average of apparent loss, real loss, and NRW from 2010 to 2014 was approximately $19.5 \%, 21 \%$, and $40 \%$ respectively. It was estimated that the average annual cost of NRW between the years 2010 and 2014 was approximately 9.4 million USD, which was approximately $33 \%$ of the total revenue budget. In conclusion, there is a need for the development of water management systems to provide the best management practice system to further minimize NRW problems in Oman.
\end{abstract}

\section{Introduction}

Water is an invaluable source not only for human life but also for all the living forms in this universe. The water supply utilities should fulfil the water condition quantitatively and qualitatively. One of the main problems affecting water supply systems in developing countries is the problem of water losses, which includes apparent water losses and real water losses [1]. According to Petroulias et al. [2] and as per the definition of International Water Association (IWA), the non-revenue water (NRW) represents the difference among the volume of water that enters the network and the volume of water authorized for consumption (revenue water).

In Oman, water supply utilities are still run by a government authority, namely, Public Authority for Electricity and Water (PAEW). According to the PAEW, the water systems in Muscat face a several of difficulties such as low scope, low administration levels, issues with pressure driven plans, high NRW, visit pipeline blasts, issues with charging and gathering of income, and flawed water meters.

\footnotetext{
*Corresponding author: mabushammala@mec.edu.om
} 
Water misfortune, which is the real part of NRW, has been one of the significant difficulties in overseeing water utilities everywhere throughout the world and it is much additionally difficult and genuine in creating nations like Oman. This is exasperated by the way that there is an absence of mechanical skill and gear to manage water misfortune in most water utilities. Consequently, it is extremely important to have a better management of the water distribution system, as there is a need to assess the proficiency and evaluation of the execution of urban water supply frameworks in the nation.

There is no previous studies on water audit, NRW and water losses in Oman. However, the PAEW reported that the average of water losses in Oman between the years 2013 and 2016 is estimated at approximately $37 \%$ [3], which is higher compared to the international standard recommended by the American Water Works Association (AWWA) Leak Detection and Water Accountability Committee where anything less than $10 \%$ is acceptable [4]. High levels of NRW reflect huge volumes of water being lost. It affects the financial viability of water utilities through lost revenues and increased operational costs [5]. A high NRW level is ordinarily a surrogate for an ineffectively run water utility that does not have the administration, the self-sufficiency, the responsibility, and the specialized and administrative aptitudes important to give solid support of their populace [6]. Therefore, there is a need to minimize the water losses and NRW levels in Oman.

This paper aims to study the performance of water distribution systems in Muscat by investigating the water losses, the amounts of uncounted water (NRW), water balance, as well as its financial and operational impacts. Al Seeb water distribution system is used as a case study for this purpose. The study also provides recommendations on the best management practices to be considered in order to minimize the water losses and maintain it below the allowable national standard.

\section{Materials and methods}

\subsection{Description of the study area}

Al Seeb Wilayat is located within the Muscat Governorate and at present consists of a number of existing older towns primarily located along the coastal areas and in the north east of the wilayat known as Al Khoud, Al Mawalleh and Al Hayl (Fig. 1). Al Mabela is also an existing town that is located to the west of Seeb Wilayat. The area includes a light industrial estate occupied by small workshops and warehouses. A large percentage of the houses currently located within these towns have been provided with a fully reticulated water supply, although there are still houses that are supplied by tankers and there are also some empty pockets within the existing areas that have the potential to be developed.

The main source of water supply to the Al Seeb is from the Barka desalination plant. At present, water from the Barka desalination plant is pumped east through a DN1600 transmission and it supplies the Seeb reservoir compound and Mawalleh reservoir. Water is then pumped further east to supply the Sultan Qaboos University, Ministry of Defense, Wave and Airport reservoirs. Water conveyed from the Barka desalination plant to the Seeb reservoir is then mixed with water from the Western Wellfields.

The water in the territory is appropriated straightforwardly by a system of three kinds to be specific, Asbestos Cement (AC), Ductile Iron (DI), and High Density Polyethylene (HDPE) channels. A large number of the channels are in a terrible state since they are over 20 years of age. The transmission mains range from $150-800 \mathrm{~mm}$ in diameter and the total length pipe is $29 \mathrm{~km}$, and the distribution pipelines range from $150-800 \mathrm{~mm}$ in diameter with a total length of the network pipe of about $740 \mathrm{~km}$. 


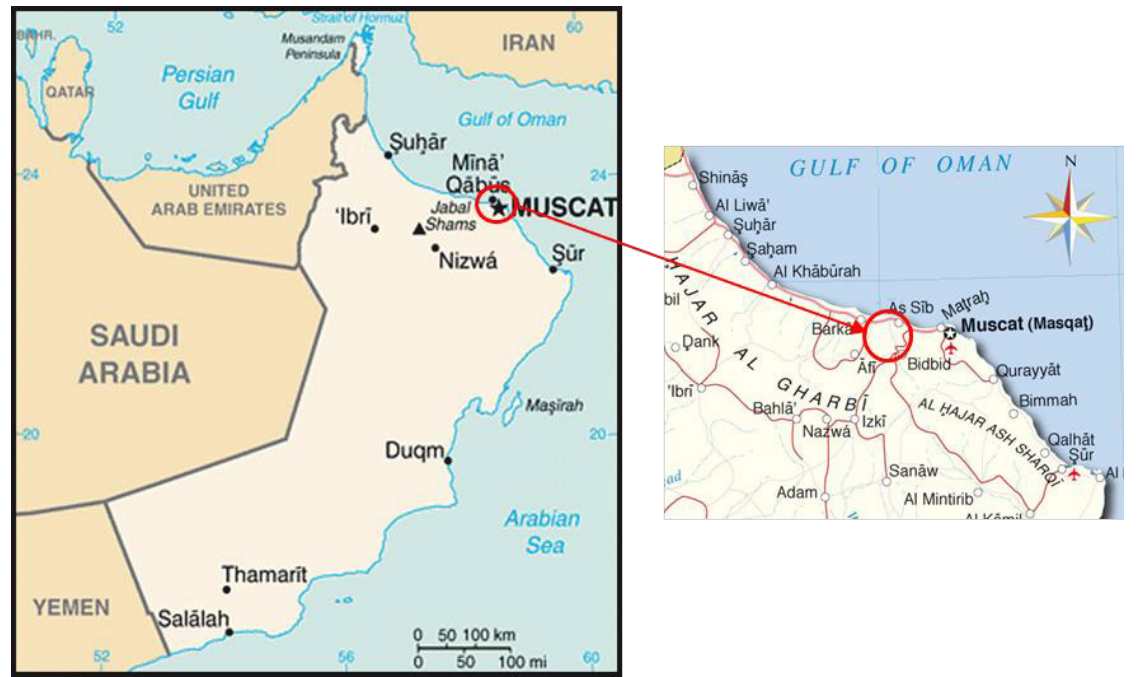

Fig. 1. Study area location.

\subsection{Determination of NRW}

\subsubsection{Data collection}

The annual data on water supplies, water consumption, system data, and cost data from 2010 to 2014 were required in order to use the AWWA audit software to determine the annual water losses in the water distribution networks of the study area. Thus, thirteen staff working on water leakage and NRW form head offices and other offices of PAEW were interviewed to get out in-depth information of their knowledge, perceptions and experience with the current situation and future strategy for NRW and water losses, and their understanding of the main causes of water loss. Furthermore, the interviews were mainly aimed at collecting information necessary for water auditing using AWWA Water Audit Software to calculate water losses including real and apparent losses, NRW, water balance, and cost [7]. Data sheet was prepared and used during the interviews in order to collect the required data and information. The data sheet was divided into two sections; the first section, respondents have to fill basic information about the name of city or utility with full address and year of reporting, and the second section is reporting work sheet which includes the data of water supplies, authorized consumption, apparent loss, system data, and cost data.

\subsubsection{AWWA Water Audit Software}

Based on the standard water balance International Water Association (IWA) shown in Table 1 [8], the AWWA developed Water Audit Software [9], which was used in the current study. The software was designed in excel Microsoft office with a number of working sheets. Once data entries are accomplished, the program calculates losses, revenue and NRW and the detail water balance. Thus, the collected data were entered into the software, and the results were generated and presented in a water balance sheet with defined international terminology. The figures obtained in the water balance were calculated from the measurements and estimation of water input to the system, water consumption, and water losses. 
Table 1. IWA standard water balance.

\begin{tabular}{|c|c|c|c|c|}
\hline \multirow{9}{*}{ 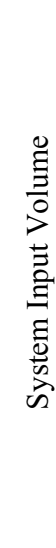 } & \multirow{4}{*}{$\begin{array}{l}\text { Authorized } \\
\text { consumption }\end{array}$} & & $\begin{array}{l}\text { Billed Metered Consumption (including } \\
\text { water exported) }\end{array}$ & \multirow[t]{2}{*}{$\begin{array}{l}\text { Revenue } \\
\text { Water }\end{array}$} \\
\hline & & $\begin{array}{l}\text { Authorized } \\
\text { Consumption }\end{array}$ & Billed Unmetered Consumption & \\
\hline & & \multirow{2}{*}{$\begin{array}{l}\text { Unbilled } \\
\text { Authorized } \\
\text { Consumption }\end{array}$} & Unbilled Metered Consumption & \multirow{7}{*}{$\begin{array}{l}\text { Non- } \\
\text { Revenue } \\
\text { Water }\end{array}$} \\
\hline & & & Unbilled Unmetered Consumption & \\
\hline & \multirow{5}{*}{$\begin{array}{l}\text { Water } \\
\text { Losses }\end{array}$} & \multirow{2}{*}{$\begin{array}{l}\text { Apparent } \\
\text { Losses }\end{array}$} & Unauthorized Consumption & \\
\hline & & & Metering Inaccuracies & \\
\hline & & \multirow{3}{*}{ Real Losses } & $\begin{array}{c}\text { Leakage on Transmission and/or } \\
\text { Distribution Mains }\end{array}$ & \\
\hline & & & $\begin{array}{c}\text { Leakage and Overflows at Utility's } \\
\text { Storage Tank }\end{array}$ & \\
\hline & & & $\begin{array}{c}\text { Leakage on Service Connections up to } \\
\text { point of } \\
\text { Customer Metering }\end{array}$ & \\
\hline
\end{tabular}

\section{Results and discussion}

\subsection{Water losses and NRW}

The values and percentages of water losses and NRW were obtained as per the volume of water. The percentage values of apparent losses, real losses, and NRW for are shown in Fig. 2.

The data presented in Fig. 2 shows that the average amount of NRW between the years 2010 and 2014 is $40 \%$. The percentage of NRW was decreased in year 2010 from $46.7 \%$ to reach $36.2 \%$ in year 2014 , with an approximately $22.5 \%$ reduction rate. This reduction in NRW might be due to the continuous efforts of the PAEW to improve water supply system in the study area. Figure 2 also shows that the average percentage of apparent water loss is around $20 \%$ which is comparatively a high percentage. These types of water losses resulted from metering errors, water theft, and billing anomalies. The percentage values of real losses are also high as apparent losses which might be refer to the leaks in transmission and distribution pipelines, overflow of water from reservoirs and water tanks, and leaks in house connections. The results also show that the percentage values of real losses during 2013 and 2014 were comparatively reduced in contrast to the years 2010 and 2011; the percentage decreased from $25 \%$ in the year 2010 to reach $15 \%$ in the year 2014 . 


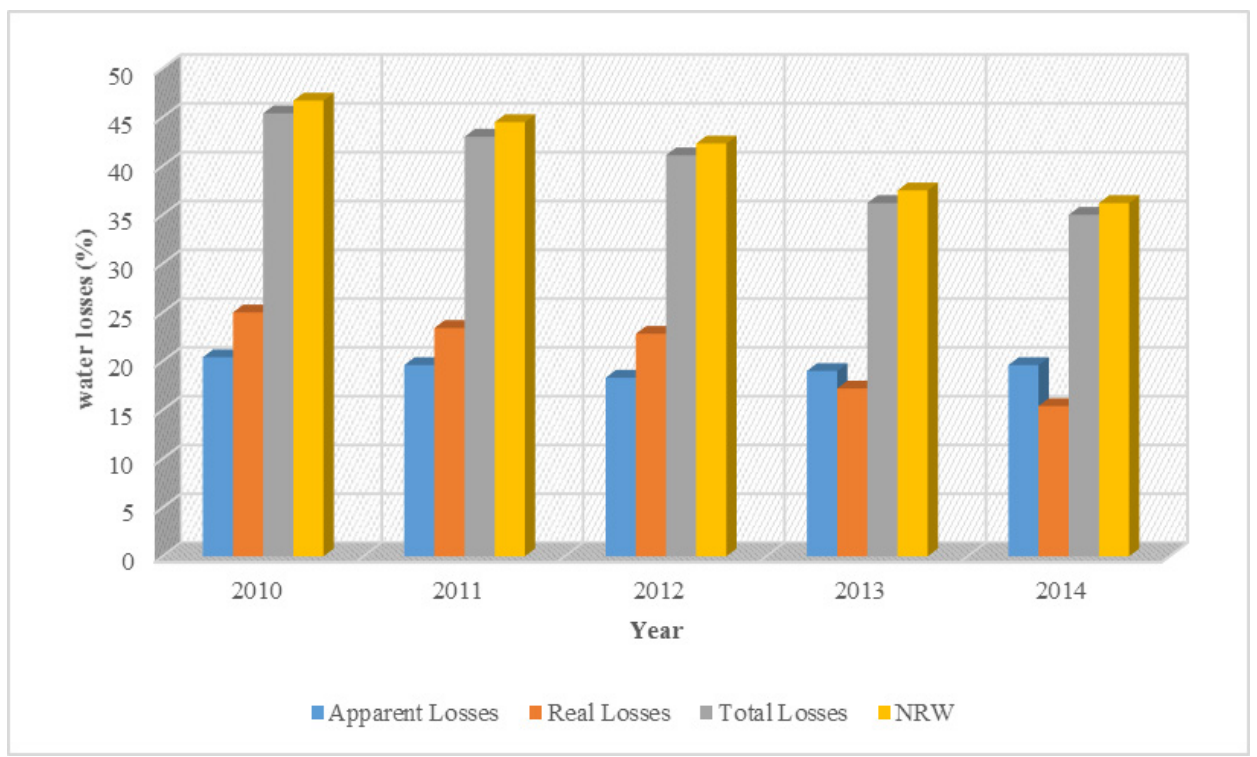

Fig. 2. Percentage values of water losses.

\subsection{Performance indicator}

The performance indictors including financial and operational indicators were also determined. They indicated the efficiency performance of the water system. The results of financial indicator of water losses and NRW are listed in Table 2.

Table 2. The annual cost of water losses and NRW as percent of cost.

\begin{tabular}{|c|c|c|c|}
\hline \multirow{2}{*}{ Year } & \multicolumn{2}{|c|}{ Annual cost of water losses } & \multirow{2}{*}{$\begin{array}{c}\text { NRW as percent of } \\
\text { cost (\%) }\end{array}$} \\
\cline { 2 - 3 } & $\begin{array}{c}\text { Apparent losses (million } \\
\text { USD) }\end{array}$ & $\begin{array}{c}\text { Real losses (million } \\
\text { USD) }\end{array}$ & 57.8 \\
\hline 2010 & 3.46 & 5.78 & 43.9 \\
\hline 2011 & 3.40 & 5.60 & 45.0 \\
\hline 2012 & 3.80 & 6.45 & 33.5 \\
\hline 2013 & 4.08 & 5.02 & 31.7 \\
\hline 2014 & 4.50 & 4.79 & \\
\hline
\end{tabular}

The average of total annual cost of water losses between the years 2010 and 2014 is about 9.4 million USD as shown in Table 2 as a result of high level of water losses. The results also show the percentage of NRW as percent of cost which was more than $30 \%$ in year 2014 was almost similar to the value of NRW as percent of water volume.

Two operational indicators were determined for the water supply system under the study, namely, the misfortunes per benefit association every day and Infrastructure Leakage Index (ILI). The information of evident and genuine misfortunes per benefit association every day (Liter/association/day) and ILI are presented in Table 3. 
Table 3. Operational efficiency indicators.

\begin{tabular}{|c|c|c|c|}
\hline \multirow{2}{*}{ Year } & \multicolumn{2}{|c|}{$\begin{array}{c}\text { Losses per service connection per day } \\
\text { (Liter/connection/day) }\end{array}$} & $\begin{array}{c}\text { Infrastructure Leakage } \\
\text { Index (ILI) (Real losses/ } \\
\text { Unavoidable Annual Real } \\
\text { Losses; UARL) }\end{array}$ \\
\cline { 2 - 3 } & Apparent losses & Real losses & 7.0 \\
\hline 2010 & 568.1 & 697.5 & 5.8 \\
\hline 2011 & 477.9 & 578.6 & 6.0 \\
\hline 2012 & 479.8 & 599.4 & 4.5 \\
\hline 2013 & 490.6 & 444.1 & 3.9 \\
\hline 2014 & 492.7 & 385.8 & \\
\hline
\end{tabular}

The estimations of obvious misfortunes per benefit association per day were almost similar with differences not more than $19 \%$. The estimation of genuine misfortunes per benefit association every day is reduced from 697.5-liter/connection/ day in year 2010 to 385.8 liter/connection/day in year 2014 due to reduction in real losses. The value of ILI in 2014 is 3.9; this value is less satisfactory in terms of water losses where the point of reference is 1.0 .

\subsection{Water balance}

The water balance of the study area was obtained from 2010 to 2014 . The water balance indicated clearly that around half of the water supplied in the year 2010 was without revenue and was considered as losses, but the condition has improved during the years 2013 and 2014 due to the enhancement of the management of the water network to achieve a $63.8 \%$ in the revenue of water in 2014 .

The clear misfortunes incorporate a wide range of mistakes related to client metering and in addition information taking care of blunders (meter perusing and charging), notwithstanding the unapproved utilization (robbery or unlawful utilize). The estimation of clear misfortunes is relatively consistent amid the five years (around 20\%), which may be a direct result of information taking care of blunders identified with the execution of charging and accumulation organization, or because of the client metering mistakes and unlawful associations.

The unbilled approved utilization may incorporate things, for example, firefighting and preparing, flushing of mains and sewers, road cleaning, watering of city gardens, open wellsprings, ice insurance, and building water, and so on. The consequences of water evaluating demonstrate that the rate estimation of this approved utilization amid the years 2010 and 2014 is inside $2.0 \%$ as it were.

\subsection{Water losses control and recommendations}

After studying the water balance and performance of Al Seeb water supply system, and in order to provide recommendations on how to minimize the problem of water losses and NRW, a set of interviews have been conducted with experts in the field of water supply and also with the engineers working in different departments at the PAEW. The results show that in addition to the strategy proposed by the PAEW which included a proper organization, adequate training, appropriate equipment, technology, and appropriate contractual tools [10], there are six controlling factors that influence water losses and NRW in distribution systems. They are:

- Speed and quality of repairs

- Renewal of the water network

- Leakage control 
- Pressure management

- Public education program

- Information system development

The control of these factors might cause further reduction of water losses and NRW problem control in the country. Furthermore, it is recommended that it is necessary to build up a prediction model to predict water leakage and pipe failure in the system so as to provide rapid repair and maintenance.

\section{Conclusions}

The current study investigated the problem of water losses and NRW in Sultanate of Oman involving Al Seeb Wilayat water supply system as a case study. The results revealed that the typical value of water losses and NRW in Oman is approximately $40 \%$, which is very high according to the international standards. Also the results show that the main factors that contributed to water losses are the estimation method of water consumption due to meters inaccuracies, and excess water pressure in some parts of the network. On the other hand, the financial impact posed by the NRW was found to be $32 \%$ of the total revenue budget. It is concluded that there is a real need to establish a water management system, which would be able to develop the best management practices to further minimize the problems of water losses and NRW amounts in compliance with the international standards (of less than 10\%). Furthermore, the study indicated the need for developing a water leakage prediction model to detect water leakage and pipe failure in the system in order to provide rapid repair and maintenance.

The authors are appreciative for the monetary help given by the Research Council of Oman (TRC) under the Faculty Mentored Undergraduate Research Award Program (FURUP).The authors also gratefully acknowledge the PAEW staff for their assistance with this research.

\section{References}

1. M. E. Fontana, D. C. Morais, Decision model to control water losses in distribution network. 26, 688-697, (2016)

2. N. Petroulias, D. Foufeas, E. Bougoulia, Procedia Engineering 162, 559-567, (2016)

3. PAEW (Public Authority for Electricity and Water), Available online at: https://www.paew.gov.om/getattachment/7b9277d9-07a2-46d6-8b29-

822302d2557b/Annual-Report-2016-English. (Accessed 13 October 2017)

4. K. S. Naik, M. Glickfeld, UCLA Water Resources Group, Institute of the Environment and Sustainability, University of California Los Angeles. Available online at: https://www.ioes.ucla.edu/wp-content/uploads/water-distribution-report.pdf (Accessed 13 October 2017).

5. B. Charalambous, D. Foufeas, N. Petroulias, Water Utility Journal 8, 25-30, (2014)

6. I. Dimaano, Water Science and Technology: Water Supply 10, 50-58, (2015)

7. AWWA (American Water Works Association), American Water Works Association, 1-405, (2016)

8. M. Mastaller, P. Klingel, Water Science and Technology: Water Supply, 7, (2017) 
9. AWWA (American Water Work Association), American Water Works Association. Available online at: http://www.awwa.org/. (accessed 15 April 2015)

10. PAEW (Public Authority for Electricity and Water), Available online at: https://www.paew.gov.om/Our-role-in-Oman/Reduce-water-losses. (accessed 05 May 2015) 